\title{
Principled Nonviolence: An Imperative, Not an Optional Extra
}

\author{
Kevin P. Clements
}

This article compares principled and strategic nonviolent movements. While pragmatic, strategic nonviolence is effective for movements seeking to overthrow corrupt repressive and dictatorial regimes, it is much less successful in the progressive transformation of state and political systems. This is because principled nonviolence and movements associated with such value systems are ambivalent about political power and the role of the Weberian state. Conversely strategic nonviolent movements are willing to utilize the coercive power of the state for their own political purposes and in doing so often become fatally compromised, as happened in Egypt, Palestine and Syria. The promise of principled nonviolence is social, political, and economic institutions capable of transcending Machiavellian politics because of a radical commitment to pacifism and emancipatory political processes.

Keywords principled nonviolence, strategic nonviolence, Mahatma Gandhi, Martin Luther King, transformative politics

"Violence is the behaviour of someone incapable of imagining other solutions to the problem at hand." Bruno Bettelheim

"I oppose all violence because the good it does is always temporary but the harm it does is permanent." Mahatma Gandhi

"Nonviolence is a Weapon of the Strong." Mahatma Gandhi

"Nonviolence is fine as long as it works." Malcolm X

"Nonviolence is a flop. The only bigger flop is violence." Joan Baez

"To kill one man is to be guilty of a capital crime, to kill ten men is to increase the guilt ten-fold, to kill a hundred men is to increase it a hundred-fold. This the rulers of the earth all recognise and yet when it comes to the greatest crime-waging war on another state-they praise it..." Mozi (China 470-391 BC) 


\section{Principled vs. Pragmatic Nonviolence}

Analyzing why individuals, groups, movements, organizations, and nations resort to (direct or indirect) violence to satisfy their interests and needs is perhaps the major problematique of peace and conflict studies. Analyzing individual, group, movement, and national alternatives to violence has not, however, received anywhere near the same amount of academic attention as has violence. This is partly because violence is assumed to be more interesting and sexier than nonviolence ("if it bleeds, it leads"), but it also reflects the fact that even in the richly normative discipline of peace and conflict studies we tend to be much more concerned with pathology than cure.

One of the reasons for the relative neglect of nonviolence is that there is no single term that adequately explains what it is all about. Is it an ethical belief, an attitude, a tactic, or a strategy, or all of the above? What has motivated people in the past and what motivates people in the present to choose nonviolence in response to life's many dilemmas? Why in the second decade of the 21 st century has there been an upsurge of both academic and political interest in nonviolence?

There are many answers to all these questions. In the first place, it is clear that within most major religious and philosophical traditions nonviolence is viewed as a superior way of living-something to aspire to. These religious traditions developed what is known as "principled nonviolence." This was, and is, seen as more virtuous than the old warrior traditions. Christians, for example, are enjoined to love their enemies; Hindus and Buddhists to observe the oneness of all things and not harm life; Taoists and Confucians to search for harmony as a universal truth principle. All of these religious traditions highlight the value of principled nonviolence. Nonviolence is a way of both understanding and living "truth" in the face of the physical, psychological, and moral vulnerability that flows from each one of us living in the company of others.

Principled nonviolence is based on a rejection of all physical violence. It rests on a willingness to suffer instead of inflicting suffering, a concern to end violence, and a celebration of the transformative power of love and compassion. Nonviolence is seen as an outward manifestation of a loving spirit within each one of us. Recent neuroscience, incidentally, underlines that what world religions view as love may in fact be hard wired into our right-brain instincts for connection and bonding (McGilchrist 2009, 156). Principled nonviolence seeks to love potential enemies rather than destroy them, and promotes nonviolent, peaceful means to peaceful ends. Its preferred processes are persuasion, cooperation, and nonviolent resistance to forceful coercion for political purposes.

Mahatma Gandhi was probably the most exemplary representative of this tradition. His whole life was dedicated to the nonviolent pursuit of justice and peace and to the principle of doing no harm to others. He wanted to build 
communities and nations based on positive, nonviolent principles. Gandhi distinguished between "nonviolence for the weak," which is the use of nonviolent techniques in resisting oppression (what is now thought of as tactical or strategic nonviolence), and "nonviolence for the strong," which is a permanent nonviolent lifestyle for those with resources, power, and influence. Nonviolence for the strong involves self-discipline, simple living, an inner search for truth, and the courage to confront injustice and oppression by nonviolent means (Dalton 2012). This principled nonviolent tradition has over the years given rise to the Civil Rights Movement in the United States and fuelled many of the principled and pragmatic nonviolent political movements of the 21st century. It has been successful, for example, in places like Poland, the Philippines, and many countries in the former Soviet Union. Nonviolence as a way of life provides a powerful moral compass for evaluating whether different kinds of social movements, or economic, social, and political decisions, are likely to generate sustainable development and stable peace over the medium-to-long term.

The second understanding of nonviolence is what is known as pragmatic, tactical, or strategic nonviolence. Some critics refer to this perspective as "nonviolence light." This is a little unfair since many of the people who engage in tactical and strategic nonviolence often exhibit considerable courage when confronting oppressive regimes and deep-rooted injustice. The reason it is considered nonviolence light, however, is because it does not demand a commitment to personal pacifism or a nonviolent lifestyle. Pragmatic nonviolence simply asserts that physical violence is too costly or impractical; it is grounded in political struggle and is seen as an effective method or tool for generating political change. Instead of asking what is right, it asks what will work. Pragmatic nonviolence is a means to an end rather than an end in itself. It aims at short-term goals (e.g., the overthrow of a repressive regime, or changes to unjust and oppressive laws) rather than an end to all violence in all spheres of social life. Pragmatists see no particular problem in utilizing nonviolent tactics or strategies to overthrow a regime and then utilizing all the machinery of government (including its coercive security, police, and military capacities) to maintain order for the benefit of their own groups and interests. Principled nonviolent actors, on the other hand, always feel somewhat suspicious about power and the circulation of power elites. They are certainly wary of assuming responsibility for the monopoly of force and power at the heart of most state systems. Pragmatic nonviolence is not averse to the use of coercion-especially psychological and economic coercion. But it draws the line at physical coercion for regime change. Having achieved power, however, pragmatic nonviolent movements are willing to utilize physical coercion on behalf of the new regime. The principle concern of strategic, pragmatic nonviolence is to resist oppression, build mass-based movements, lower the entry and participation requirements, and ensure that they are effective instruments for waging a range of political struggles. Gene Sharp, 
one of the principal advocates of strategic nonviolence, argues that "nonviolence is what people do, not what they believe. Nonviolence is an alternative weapons system" (Sharp 1973, 110). Because of this philosophical position, strategic nonviolence focuses a lot of attention on articulating and promoting a wide range of nonviolent protest tactics, including the withdrawal of cooperation or noncooperation (with private and public sector actors), and civil disobedience to unjust customs, norms, and laws.

The good news is that pragmatic, strategic nonviolence has often proven effective in civilian resistance to oppression (Chenoweth and Stephan 2011); the bad news is that many of these successful examples of pragmatic nonviolence have not proven so successful over the long haul. Many (e.g., the Moslem Brotherhood in Egypt) have come to power but have refused to grapple with many of the deeper sources of both direct and indirect violence, and have wittingly or unwittingly perpetuated popular preoccupation with state power, politics, and coercive agency. This is why I wish to argue that principled nonviolence is an imperative, not an optional extra. Principled nonviolence is capable of embracing all the tactics and strategies of strategic nonviolence, but it always maintains a critical wariness of the monopoly of violence at the heart of every state. Like strategic nonviolence, it encourages the development of grassroots capabilities, legitimacy, and resilience, but it is aimed at long-term rather than short-term solutions. It will work with the state when appropriate and oppose it when not. It derives its legitimacy and power from values that cannot be compromised. It does this by continual self-critique as well as by a robust commitment to constant change for a more just and peaceful world. It knows that simply overthrowing an unjust, repressive system is no guarantee of long-term justice and peace. It is the misplaced focus on the state that is proving to be the Achilles heel of strategic nonviolence.

\section{Nonviolence and the State}

This raises an important question: Why do all change agents (whether from a principled or pragmatic nonviolent tradition) focus so much attention on the state? One reason is that the state's monopoly of coercive capacity, force, and violence defines and shapes the ground rules for both pragmatic and principled nonviolence. We can't avoid this. If we are to map the contours of violence then it is imperative that we understand who is dominant, who subordinate. Who is in and who is out. Who has power and who is relatively or absolutely powerless. My argument, however, is that principled nonviolent action is committed to seeing beyond "normal politics" to discern alternative political and human possibilities. This orientation generates a radical challenge to both the state and wider economic and social sources of direct, structural, and cultural violence. There is 
nothing in pragmatic nonviolence that will necessarily or automatically move it in a more radical direction.

One of the reasons we are so preoccupied with the nation state is because state systems, in modern industrial economies, have an enormous capacity to determine social, economic, and political outcomes for people, and we know that they directly or indirectly have a critical role to play in terms of levels of wellbeing, cooperation, harmony, and peace. The downside of this fascination, however, is that social movement activists and leaders-and even peace researchers-become seduced by the logic of state power and in different ways reinforce it by and with their/our particular academic and political preoccupations.

Recently, for example, in the academic field of Peace and International Relations there has been an upsurge of interest in the utility of nonviolent social movements for regime change and wider social and political transformation. The Journal of Peace Research (JPR), for example, dedicated its May 2013 issue to "Understanding Nonviolent Resistance" (Chenoweth and Cunningham 2013). In this issue there are a number of articles outlining the diverse ways in which nonviolent social and political movements have been successful in relation to self-determination movements, regime change, and general political struggles for human rights and other issues. This issue of JPR focuses attention on such things as resource mobilization, decreasing barriers to participation, coalition formation, tactics, strategy, discipline, elite defections, and the positive utility of "backfire" in resisting oppressive rule. Most of the papers "demonstrate the importance of treating nonviolent and violent strategies, as well as conventional political strategies, as alternative choices for engaging the state" (ibid., 271). Or as Chenoweth says, "Improved theory and data on the subject will help researchers and policymakers to shape strategies to support these movements when appropriate, and to manage changes in the international system that result from the success of nonviolent uprisings" (ibid.).

These comments continue the preoccupations of an earlier paper on "Why Civil Resistance Works: The Strategic Logic of Nonviolent Conflict" (Stephan and Chenoweth 2008) and more recently Erica Chenoweth and Maria Stephan's award-winning book on Why Civil Resistance Works (Chenoweth and Stephan 2011). I will return to some of their key issues later in the paper.

All of these recent contributions on the effectiveness of nonviolent tactics and strategy for political transformation are being proposed for pragmatic purposes and are seen by many critics as simply enlarging the number of nonviolent options available to protest movements around the world. It seems likely that the upsurge of recent interest in these movements springs from the desire of a range of political parties and movements to adopt or co-opt them because of their low entry costs and their effectiveness in building mass movements, rather than from any ideological or ethical commitment to a radically nonviolent future.

In this sense strategic and pragmatic nonviolence is primarily a 21 st century 
means of waging nonviolent political struggle in order to change repressive national and global political systems in a democratic and Western direction. These movements are, therefore, a very integral part of the wider liberal peace project (see Newman, Paris, and Richmond 2009). There is no deeper inclination or commitment to linking nonviolent means to nonviolent ends or to advancing local level solutions to locally driven problems. Many of the movements and parties adopting strategic nonviolence are doing so to advance liberal peace by non-coercive means. This suits the Western liberal peace agenda very well indeed. There are numerous examples of nonviolent means being used to overthrow a dictatorship or repressive rule without any future commitment to a more just or nonviolent future. As mentioned above, once repressive rulers have been overthrown, the leaders of strategic nonviolent movements see little or no contradiction between their nonviolent means and taking over all the old dictator's machinery of government and coercive capacities.

Strategic nonviolence, in these instances, does not extend to an ongoing deepening of nonviolent, pacific values or the emergence of state systems that are less dependent on force than those which have been replaced. Thus it seems to me that many of the sanguine predictions for the power of nonviolent civil resistance might need to be modified over the medium-to-long term.

Strategic nonviolent tactics have been promoted tirelessly by the International Centre of Nonviolent Conflict (ICNC). Those associated with this organization have done a huge amount of work promoting pragmatic and strategic nonviolence. In doing so they have equipped a wide range of different groups and social and political movements with useful tactics and strategies for resisting political oppression and dictatorship. And they have been successful. Many recent nonviolent revolutions owe their success to the work and ideas of the ICNC. This organization can claim credit for overthrowing dictators, which is an important prerequisite for nonviolent transformation. But apart from ensuring that dictators don't return, it is not primarily interested in transformational processes beyond opposition to repressive and oppressive rule. In fact, the ICNC specifically rejects the value or importance of principled nonviolence as unnecessary or irrelevant to the strategic logic of nonviolence. This means that they are more interested in short-to-medium term, strategic effectiveness rather than changed social values or long-term social and political transformation. The mission of the ICNC is to promote the strategic utility and effectiveness of nonviolent resistance as a political weapon. They assert that "Nonviolent conflict is a way for people to fight for rights, freedom, justice, self-determination, and accountable government, through the use of civil resistance-including tactics such as strikes, boycotts, protests, and civil disobedience" (http://www.nonviolent-conflict.org).

Note the stress on "fight" and how much of the focus of these fights is on civil resistance directed primarily, but not exclusively, at corrupt, repressive, unaccountable, and unjust governments. The ICNC is interested primarily in 
expanding the repertoire of nonviolent options for civil resistance to unjust and oppressive rule. I am not opposed to these ICNC initiatives. In fact, I encourage them. It is definitely better to promote tactical and strategic nonviolent opposition to dictatorship and repressive rule than disorganized nonviolent activism, or worse, violent opposition to such rulers.

To the extent that these tactics have been effective in the Middle East (Celestino and Gleditsch 2013) and elsewhere, the ICNC, and other individuals and groups promoting pragmatic rather than principled nonviolence, can take credit for successfully focusing on nonviolence as a political strategy rather than a way of life (Dudouet 2013). They see these successful social movements as vindication for a pragmatic, non-threatening nonviolence.

While personally they might be interested in particular goals, as a political movement the ICNC and similar groupings are not that interested in moral values, short- or long-term political vision, or in ethical means/ends relationships. They are primarily interested in what works and what is politically effective. In their view most individuals and communities are happy to adopt nonviolent tactics but not so willing to adopt pacifism and nonviolence as personal guiding principles. Deeper values may be important to individuals, but as long as pragmatic nonviolence works, and as long as it is less personally or politically costly than violent options, pragmatists advocate nonviolence primarily for instrumental reasons.

The advocates of strategic nonviolence are very reluctant, therefore, to accept the demands of principled nonviolence or pacifism. They argue that there is no particular reason why nonviolent political activists have to have any "principled" justifications for their behavior. In fact they argue that principled nonviolence (nonviolence as a way of life) is often an impediment to effectiveness. Principled actors, for example, might be too empathetic towards their opponents and not "tough" enough! Their justification for pragmatic nonviolence is largely utilitarian. It lies in the "success" of the movements. If millions of people over the past 50 years have taken to the streets in "successful" nonviolent protest movements, this justifies pragmatic nonviolence. Most of the recent scholarship on these movements, therefore, has focused on tactics that have generated movement success in replacing regimes, securing independence, and reducing oppression. Theorists and advocates of strategic nonviolence argue that if these goods can be achieved with pragmatic nonviolence why would theorists or activists seek to complicate things with more "idealistic" aspirations?

\section{Limitations of Pragmatic Nonviolence}

Well before the current spate of papers and books eulogizing pragmatic nonviolence, L.K Bharadwaj argued the opposite case. He suggested a 
fundamental difference between pragmatic and principled nonviolencean irreconcilable difference between (for example) Gandhian nonviolence and pragmatic nonviolence, which he describes as a species of "moderate Machiavellianism" (Bharadwaj 1998, 79-81). Machiavelli (the first systematic exponent of cynical realism) suggests that "immorality is the very law of politics." This is because success is all that is important to the ruler. He/she will justify any and all means in the pursuit of desirable political ends. This could mean, for example, torture, manipulation, subversion, war, propaganda, collective brainwashing, and so forth. Absolute Machiavellianism is willing to sacrifice everything on the altar of success. "Moderate Machiavellianism" on the other hand has slightly clearer normative boundaries, but if the moderate way fails Machiavellian logic will generate a willingness to contemplate, if not subvert, nonviolent, peaceable processes.

Max Weber made similar comments in his lecture "Politics as a Vocation" where he argued:

\begin{abstract}
"The decisive means for politics is violence." Against the prominent German pacifist and Great War opponent, E W Forster, he claimed "it is not true that good can follow only from good and evil only from evil, but that often the opposite is true. Anyone who fails to see this, is indeed, a political infant...Anyone interested in saving their soul should not seek it along the avenue of politics, for the quite different task of politics can only be solved by violence." ... [In response to the biblical injunction to turn the other cheek, Weber argues:] "for the politician, the reverse proposition holds, Thou shalt resist evil by force." (Howes 2013, 427)
\end{abstract}

In opposition to this position, Bharadwaj argues:

As long as nonviolence is embraced on pragmatic grounds; and, not truth and morality, but success and power (in the Weberian sense of the imposition of our will on the other, in spite of the other's resistance) are made the criteria of its efficacy, it prepares itself for self defeat. (Bharadwaj 1998, 79)

The reason for this is that the focus on political success is likely to lead to an opportunistic and half-hearted acceptance of nonviolence. It will be embraced as long as it is successful; but if it encounters deeper resistance or failure, as was the case in Syria, there will be a temptation to use other, more expedient or violent means.

This willingness to compromise or explore alternatives to nonviolence will eventually lead to the destruction of good ends and means. This argument has been vindicated in Egypt and Tunisia over the past year (Gresh 2013). Without deep commitment to principled nonviolence, individuals, groups, and movements in both countries have been prepared to consider cynical nonviolence (such as nonviolent demonstrations under the auspices of the military and security forces) 
or more violent options to secure economic, social, or political advantage.

Gandhi (and his disciple Martin Luther King), on the other hand, both want to preserve the purity of means and ends at all costs. They assert

the unity and integrality of means and ends, treating truth and nonviolence as convertible terms (two sides of the one coin).... [Gandhi] would rather that one use violence, or even "kill rather than be a coward" than accept nonviolence merely on pragmatic grounds or for reasons of expediency. (Bharadwaj 1998, 80)

The proponents of pragmatic nonviolence apply a minimal political principle of doing no physical harm to those they politically oppose. The advocates of principled nonviolence, on the other hand, apply a principled rejection of the use of physical or emotional violence in all personal and political life. They do not see nonviolence as a short-term, rational choice for particular political ends; rather, it is a way of life and being. The challenge is how to hold the principled and pragmatic in tension. Gandhi was definitely the leading advocate of principled nonviolence, but he was also willing to resort to pragmatic, tactical nonviolence for different types of political objectives. The difference between Gandhi and contemporary pragmatists, however, is that his pragmatic nonviolence always took place within a much more demanding principled framework. Gandhi was never happy with the short-term political gains he and his followers achieved as he knew that generating a non-violent world demanded personal and collective commitment to pacifism on a daily basis and for the long haul.

If we take two examples of principled nonviolent action-the Indian Struggle for Independence and the United States Civil Rights Movement-it is clear that analysts and activists in both movements were as concerned with the peaceful consequences of their processes as they were with the outcomes. They felt uneasy with processes that did not accord as much respect to their opponents as to their followers. Because of this they subjected their politics to much more radical and critical scrutiny than do those that are opportunistically nonviolent. If our goal is to be in peaceful relations with fellow human beings at all levels and in all sectors through time, then this is a much more demanding and radical proposition than simply applying nonviolence to achieve immediate political objectives.

In recognition of this, nonviolent actors, such as War Resisters International (WRI), have developed specific principles of nonviolent action. They know that many people will not be able to accept all of these principles all of the time, but these principles (most of which are some variant of Gandhi's principles) do provide a reasonably clear normative framework for guiding nonviolent behavior. Without such principles it is possible for pragmatic nonviolent movements to engage in a wide variety of opportunistic actions that might do emotional or even physical harm to opponents while changing their economic, social, or political behavior. It is also the case that without such principles, those who are 
pragmatically nonviolent will have little incentive to work for inclusive, longer term, stable peace (with justice) after political objectives have been secured. The WRI principles are stated as follows:

- We acknowledge the value of each person. This is fundamental; recognising the dignity and humanity of oneself and others. We refuse to mistreat our opponent as an enemy.

- We recognise that we all have part of the truth; no-one has all of it. No one is all "right" or "wrong." Our campaign information gathering, education and actions should reflect this.

- Our actions emphasise openness to promote communication and democratic processes. We work for processes that express "power with" not "power over" others. Empowering all involved in a campaign is important. We promote democratic structures (internally and externally) to maximise self determination.

- Our means (behaviours and actions) are consistent with our ends (of affirming life, opposing oppression and seeking justice, valuing every person). Our strategy must be based on this principle; we cannot justify a "victory" obtained through violent or deceitful methods.

- We are willing to undergo suffering rather than inflict it. Refusing to inflict suffering is based on the value of each person and is a strategy that draws attention to our commitment and our cause. We will not violently fight back if attacked. We recognise jail may be a consequence of our actions; filling the jails may be a strategy.

- We commit ourselves for nonviolent action according to the guidelines agreed. If necessary we will attempt to arrange orientation sessions or workshops in nonviolence to better understand and practice this commitment. (Clark 2009, 51)

These values are very different from the pragmatic guidelines for strategic nonviolent activists. Gene Sharp, for example, documents 198 different kinds of nonviolent action classified into three categories according to their strategic function: (1) Nonviolent protest or persuasion, (2) non-cooperation, and (3) nonviolent interventions aimed at disrupting old social relationships and/or forging new autonomous relations (Sharp 1973, 23). None of these tactics rest on any philosophical or principled positions, although a lot of Sharp's original work was a detailed analysis of Gandhian philosophy and practice (Sharp 1970). They just represent actions that have proven effective in past conflicts. They are promoted as worthwhile tactics because they are considered, or have "proven" to be, effective.

In another example, Kurt Schock, who is a very sophisticated advocate for pragmatic nonviolence, focuses on tactics that will (1) generate political leverage, (2) strengthen resilience in the face of repression, or (3) yield advice on when to concentrate or disperse movement forces in different campaigns (Schock 2005, 27). These different dimensions or tactics of successful movements could just as easily be interim tactics for the military as for nonviolent resistance movements. Military strategists, for example, will try to exhaust nonviolent options before 
contemplating violent ones because they know the costs of violence are higher than the costs of nonviolence.

Chenoweth and Stephan argue very specifically that what makes pragmatic nonviolence so effective is the low entry costs for participants. Because actors do not need to embrace moral or political principles, and do not need to worry about the dangers and costs of armed violence, they can be more easily mobilized en masse (Chenoweth and Stephan 2011).

This orientation has been vigorously promoted by the ICNC. The consequences have been varied. On the one hand there is no doubt that Gene Sharp's strategies and tactics have been widely circulated around the world. There is also no doubt that these tactics have been put to use in a range of oppressive environments with considerable success. But there are downsides as well. The ICNC has been criticized in the past for its close links with Freedom House. (Peter Ackerman, the founding chair of ICNC, is also chair of the board of Freedom House.) They have also been criticized for being too close to U.S. government policy in relation to externally sponsored, internal subversion of some odious regimes. It suits the U.S. government well to have strategic nonviolent advocates focus their attention on states considered problematic to U.S. global interests. If these regimes can be overthrown by nonviolent popular movements, that removes the need for state-to-state subversion! It certainly postpones the need for "dirty tricks" campaigns or more high-risk military interventions. So, strategic nonviolence suits big states like the United States well. If strategic nonviolence, for example, can generate elite defections from odious regimes, this avoids the necessity for the United States to engage in covert or overt military engagement and helps the toppling of "dictatorships" in a "friendly" non-coercive fashion! In this way the United States can generate more and more democratic, like-minded states all around the world without damage to its reputation or any need to engage in diplomatic threat.

In terms of outcomes, however, I would argue that in these instances there is very little to distinguish the tactics or choices of strategic nonviolent actors from actors with violent means at their disposal.

In relation to military or political defections, for example, both violent and nonviolent strategists will try to generate incentive packages to encourage elite discontent, dissent, and defection. If the strategic nonviolent inducements do not work the sanctions are more mass mobilizations aimed at paralyzing the government. If the strategic violent actor's inducements don't work, the sanction is likely to be more coercive violent threat. Both violent and nonviolent strategists therefore aim at exerting power for particular political interests. Both are a long way from the goals and aspirations of principled nonviolent actors. 


\section{Nonviolence and Political Power}

Most of the pragmatic nonviolent literature is about a re-conceptualization of power such that citizens might realize and utilize their latent capacities more effectively. This contrasts rather dramatically with the principled nonviolent activists who are interested in radically recasting power as a tool of deeper social empowerment- "power with others" rather than "power over others." Pragmatic nonviolence is about challenging those in power by withdrawing cooperation and compliance. It is about political competition by nonviolent means. Pragmatic nonviolence is not normally aimed at a fundamental rethinking of state institutions or the nature of the relationships between civil society and the state. Rather it is directed at enabling those who are relatively, or absolutely, powerless to realize their latent power so that they might (directly or indirectly) make state and political institutions work in their favor. Where state institutions are considered fragile or defective, pragmatic nonviolence is aimed at making them work more effectively and legitimately. This is not an anarchist/non-state option; it is simply a collection of methods for exerting power and influence on the part of the relatively powerless or disenfranchised by nonviolent means. It is a nonviolent political choice. The problem is that in most democratic environments this is not all that radical.

Most politics in democratic systems are nonviolent, and most social and political movements that wish to be politically effective within state systems have to play by the Weberian logic of the state rather than by a deeper radical logic of personal, interpersonal, social, and communitarian nonviolence.

Principled nonviolence, on the other hand, has a much more radical ontology. It seeks to challenge and change the militarized, dominatory, and sovereign nature of contemporary politics so that political institutions are decentered, decentralized, responsive, and truly representative of diverse social and political opinion. Principled nonviolence is always ambivalent about the state because of the iron fist that lies beneath the velvet glove of all political and judicial institutions. They are not happy with rearranging the deck chairs on the Titanic, substituting one regime for another. They want safer ships!

Principled nonviolence advocates want minimal state systems with absolutely minimal security establishments. They want deeper notions of popular legitimacy rather than claims based on a monopoly of force. ${ }^{1}$ John Burton, for example, argues that the whole point of collaborative problem solving is to challenge adversarialism wherever it occurs - within society, education, the polity, the judiciary, and the economy (Burton 1969). It would be very challenging for a Burtonian, therefore, to advocate pragmatic nonviolence because this is aimed primarily at the enhancement of adversarial tactics for very specific political purposes. 
Principled nonviolence is aimed at something else altogether. It is aimed at building radical cultures of respect, dignity, and peacefulness at social, economic, and political levels. It is not seduced only by the political. It is based on giving practical recognition to, what I would call, the politics of love and compassion. Most principled nonviolence flows from Gandhian philosophy and is based on a daily practice to wage peace. Gandhi was always looking for the "truth" in relationships and believed that if he could discover what generated deeper empathetic compassion, this "truth force" would prove more compelling than brute force. He believed in living each day with truth, justice, patience, compassion, courage, and loving kindness as his companions. These are the values and concerns that I, and most principled peace advocates, promote. This is a much more radical commitment than simply looking for effective political tactics. Gandhi's use of the ancient Hindu term ahimsa (which means not injuring or harming anyone, and being nonviolent in thought, word, and deed) actively promotes universal well-being for all species. This means a radical respect for the environment and all species, what Gandhi calls sarvodaya, or justice for all creatures (see Prakash 2013 for an elaboration of these concepts). It also involves a commitment to what Gandhi calls swaraj, or self rule, where we assume full responsibility for our own behavior and for decisions on how to organize our own communities. It stands in radical tension with what we might think of as dominatory politics. It is also based on swadeshi, or the "genius of the local," where, as far as possible, needs are satisfied from one's locality, drawing on the genius of local knowledge and skills. Finally, principled nonviolence is based on satyagraha, or nonviolent revolution, which is aimed at turning foes into friends and intolerance into hospitality. This is very different from mass-based social and political movements that assume that regime change will solve the problems of human coexistence. It is aimed at continual nonviolence, unleashing virtuous cycles from multiple acts of small goodness. They produce radical transformation by consistent altruism, goodness, and compassionate behavior. In actively resisting oppression satyagrahis understand that "there are wrongs to die for, yet not a single one to kill for" (Prakash 2013, 22).

All of these principles for a just and peaceful life are a long way from the short-term considerations of the pragmatic activist. They are a clear articulation of a living revolution, a daily revolution, a revolution that, by definition, knows no end. They are principles that give a radical edge to personal and political transformation, and the good news is that they have been embodied by many of the leaders and movements that advocate principled nonviolence-many of which join forces with strategic nonviolent movements for specific purposes; all of which would have some ambivalence about the current state-centric biases within the strategic nonviolent movement.

Most of the handbooks and manuals for principled nonviolent training (e.g., the WRI manual above) are pitched at ensuring that nonviolent movement 
processes are different from those of their opponents. If the state practices topdown exclusive decision making, for example, the movement wants bottom-up participatory and consensual decision making. If the state doesn't know how to enlarge consensual decision-making processes, then the movement wants to focus on how to do it. The WRI manual, for example, spends a lot of time defining what is meant by consensus decision making and how to develop what they call "spokecouncils" (Clark 2009). This is aimed at generating a different way of making decisions in collaboration with, rather than in opposition to, those whose values and interests are affected by the decisions. Similarly, these movements seek to embody gender, ethnic, and cultural diversity in different ways. Most if not all of them, however, have some common aspirations for a replacement of "brute force" with something more civilized.

\section{Conclusions}

The advocates of pragmatic nonviolence like to assert that their position is a viable stance between militarism and pacifism. It is realistic, entry costs are low, and it has proven highly efficacious (Zunes, Kurtz, and Asher 1999). They suggest that pragmatic nonviolence is the moral equivalent of war. I would like to take issue with this assertion and suggest that unless there is a willingness to embrace principled, pacifist nonviolence these social movements are likely to get snared by the political logic of the modern industrial state and to find themselves as messily compromised as those who advocate more coercive positions.

Social movement scholars argue that there are three major elements in relation to their success or failure: political opportunities, mobilizing structures, and framing processes (see McAdam, McCarthy, and Zahd 1996; Sharp 1980). My argument is that it is in the popular and elite framing of the movements that we will discover whether or not they have transformative potential, or are simply conducting politics by other means. The short- medium- and long-term successes of strategic nonviolence will be determined, not by the efficaciousness of tactics, but by whether or not the leadership of these movements and their followers embrace principled nonviolence. Without a significant leavening of the pragmatic and strategic lump these movements are simply engaged in political competition by nonviolent means.

With more principled commitments they will become constant, agonistic irritants to the taken-for-granted powers of global economics and politics. Without this radical critical edge they may generate the illusion of change, but the dynamics will be just as unpeaceful, just as unjust, as the politics they seek to replace. What has happened to the 1979 Iranian Revolution (termed a successful nonviolent campaign by Chenoweth and Stephan)? Or the first Palestinian Intifada? Or People Power in the Philippines? (Chenoweth and Stephan 2011). 
Because they were not imbedded in principled nonviolent movements their longterm impacts have been mixed, both in terms of justice and peacefulness. The reality is that while all of these movements generated positive outcomes in the short term, they have not been able to transform these results into long-term positives because the leadership did not have the mental, moral, or value-based discipline to maintain peace and justice by peaceful means.

The world has become a more peaceful place, not just because effective and legitimate state systems and the rule of law have been expanded (Pinker 2011), but because there has been a growing normative recognition of the unacceptability of violence as a political or social means of control. This message and this norm have been upheld through the centuries by religious and non-religious actors who have been willing to articulate a principled and ethical position affirming life and maintaining the unacceptability of direct or indirect violence. It is a normative position that needs to be constantly reiterated, but it's the right one if we are to be the social and political change that we want to realize. Very little attention has been directed to the attitudinal or behavioral consequences of these values in the assessment of strategic nonviolence, and yet it has been carefully nurtured and promoted by principled nonviolent advocates for centuries. Does it matter whether actors are principled or pragmatic re nonviolence as long as the strategy and tactics work? I want to argue that it does matter. In fact it matters a lot, especially in areas where violence is considered an acceptable political tool. It matters particularly around issues of mobilization, persistence, leverage, and outcomes. This is because there is a big difference between short-term and longterm change/transformation and outcomes.

Principled nonviolence is more likely to generate movement discipline, strategic flexibility, and critical understanding of the connections between direct oppression/structural violence and cultural violence. If there is no care, compassion, empathetic consciousness in strategic nonviolence, there is always the danger that it might result in a different kind of oppression, but nevertheless oppression, in consequence.

Principled nonviolence is an imperative, not an optional extra! It is the ethical glue that binds strategic and tactical nonviolence to its ethical heart. It is the spur that is needed to promote collaborative, open, and participatory institutions, and it is crucial to ensuring that all social systems really engage in that longer term and Herculean task of building cultures and structures of sustainable peace.

\section{Note}

1. There is a curious alignment here between left- and right-wing agendas, although there are some big differences as well. Both see the dangers of state domination of the 
economy and society. The left, however, wants to reduce or eliminate the security sphere as much as possible, while the right wants to reduce the welfare and educational spheres as much as possible. Both are interested, however, in enhancing the power of non-state actors.

\section{References}

Bharadwaj, Lakshmi K. 1998. "Principled versus Pragmatic Nonviolence." Peace Review 10 (1): 79-81.

Burton, John W. 1969. Conflict \& Communication: The Use of Controlled Communication in International Relations. London: Macmillan, and New York: Free Press.

Celestino, Mauricio R., and Kristian S. Gleditsch. 2013. "Fresh Carnations or All Thorn, No Rose? Nonviolent Campaigns and Transitions in Autocracies." Journal of Peace Research 50 (3): 385-400. doi:10.1177/0022343312469979.

Chenoweth, Erica, and Kathleen G. Cunningham. 2013. "Understanding Nonviolent Resistance: An Introduction." Journal of Peace Research 50 (3): 271-276. doi:10.1177/ 0022343313480381 .

Chenoweth, Erica, and Maria J. Stephan. 2011. Why Civil Resistance Works: The Strategic Logic of Nonviolent Conflict. New York: Columbia University Press.

Clark, Howard. 2009. Handbook for Nonviolent Campaigns, 1st ed. Bilbao: War Resisters International.

Dalton, Dennis. 2012. Mahatma Gandhi: Nonviolent Power in Action. New York: Columbia University Press.

Dudouet, Veronique. 2013. "Dynamics and Factors of Transition from Armed Struggle to Nonviolent Resistance." Journal of Peace Research 50 (3): 401-413. doi:10.1177/ 0022343312469978.

Gresh, Alain. 2013. "Shadow of the Army Over Egypt's Revolution." Le Monde Diplomatique, No. 1308, 1-2. http://mondediplo.com/2012/08/02egypt (accessed May 21, 2015).

Howes, David E. 2013. "The Failure of Pacifism and the Success of Nonviolence." Perspectives on Politics 11 (2): 427-446.

McAdam, Doug, John D. McCarthy, and Mayer N. Zald, eds. 1996. Comparative Perspectives on Social Movements: Political Opportunities, Mobilizing Structures, and Cultural Framings. Cambridge and New York: Cambridge University Press.

McGilchrist, Iain. 2009. The Master and His Emissary: The Divided Brain and the Making of the Western World. New Haven: Yale University Press.

Newman, Eric, Roland Paris, and Oliver P. Richmond. 2009. New Perspectives on Liberal Peacebuilding. Tokyo and New York: United Nations University Press.

Pinker, Steven. 2011. The Better Angels of Our Nature: Why Violence Has Declined. New York: Viking Books.

Prakash, Madhu S. 2013. "Peaceful Revolution? Gandhi's Four Paths to Get There." Yes Magazine, July 12.

Schock, Kurt. 2005. Unarmed Insurrections: People Power Movements in Nondemocracies. Minneapolis: University of Minnesota Press.

Sharp, Gene. 1970. Exploring Nonviolent Alternatives. Boston: P. Sargent Publishers.

Sharp, Gene. 1973. The Politics of Nonviolent Action. Boston: P. Sargent Publishers. 
Sharp, Gene. 1980. Social Power and Political Freedom. Boston: P. Sargent Publishers. Stephan, Maria J., and Erica Chenoweth. 2008. "Why Civil Resistance Works: The Strategic Logic of Nonviolent Conflict." International Security 33 (1): 7-44.

Zunes, Stephen, Lester R. Kurtz, and Sarah B. Asher. 1999. Nonviolent Social Movements: A Geographical Perspective. Malden, Mass; Oxford: Blackwell Publishers.

Kevin Clements is the Foundation Director and Professor of Peace Studies at the National Centre for Peace and Conflict Studies at the University of Otago, Dunedin, New Zealand. He is the author of over 165 articles and chapters on Peace and Conflict Studies and seven single-authored or edited books. E-mail: Kevin.clements@otago.ac.nz 
